\title{
Automated service quality and its behavioural consequences in CRM Environment: A structural equation modeling and causal loop diagramming approach
}

\author{
Arup Kumar Baksi*
}

Department of Management Science, Bengal Institute of Technology and Management, Santiniketan, West Bengal, India

\begin{tabular}{|c|c|}
\hline A R T I C L E I N F O & A B S T R A T T \\
\hline $\begin{array}{l}\text { Article history: } \\
\text { Received December 7, } 2011 \\
\text { Accepted } 15 \text { February } 2012 \\
\text { Available online } \\
25 \text { February } 2012 \\
\text { Keywords: } \\
\text { Automated service quality } \\
\text { CRM } \\
\text { Structural equation model } \\
\text { Bank } \\
\text { ICT } \\
\text { Behavioural consequence }\end{array}$ & $\begin{array}{l}\text { Information technology induced communications (ICTs) have revolutionized the operational } \\
\text { aspects of service sector and have triggered a perceptual shift in service quality as rapid dis- } \\
\text { intermediation has changed the access-mode of services on part of the consumers. ICT-enabled } \\
\text { services further stimulated the perception of automated service quality with renewed } \\
\text { dimensions and there subsequent significance to influence the behavioural outcomes of the } \\
\text { consumers. Customer Relationship Management (CRM) has emerged as an offshoot to } \\
\text { technological breakthrough as it ensured service-encapsulation by integrating people, process } \\
\text { and technology. } \\
\text { This paper attempts to explore the relationship between automated service quality and its } \\
\text { behavioural consequences in a relatively novel business-philosophy - CRM. The study has } \\
\text { been conducted on the largest public sector bank of India - State bank of India (SBI) at Kolkata } \\
\text { which has successfully completed its decade-long operational automation in the year } 2008 \text {. The } \\
\text { study used structural equation modeling (SEM) to justify the proposed model construct and } \\
\text { causal loop diagramming (CLD) to depict the negative and positive linkages between the } \\
\text { variables. }\end{array}$ \\
\hline
\end{tabular}

\section{Introduction}

The banking operation in India has undergone a total transformation with the introduction of technology. The conventional unidimensional service market trinity got converted to a three dimensional interactive model with service providers (banks), service employees (bankers) and customers interacting with each other through technology. The knowledge, skill and behaviour of service employees, considered as internal customers, remained critical while perceiving service quality, although automated banking services ensured disintermediation to a large extent (Khan \& Mahapatra, 2009). Conventional service quality concept has also metamorphosed with operational efficiency, security and confidentiality of information stored, reliability, accuracy and speed of transactions, virtual interfaces, IVR etc. being considered as major quality dimensions. Customers are

* Corresponding author. Tel. +91-9434155575

E-mail addresses: baksi.arup@gmail.com (A. Baksi) 
demanding new level of convenience and flexibility in addition to powerful and easy-to-use financial management tools, products and services that conventional banking operations could not offer (Hanzaee \& Sadeghi, 2010). Studies conducted by Ravi et al. (2007) revealed that automated banking transactions in India is still at its nascent stage with private sector banking responding and adapting earlier to these changes (Malhotra \& Singh, 2007). It was only in the extreme later half of 1990s that the nationalized public sector banks in India decided to shade-off its silos-based operational legacy and upgrade themselves to the digital platform. This shift of paradigm was further stimulated by the recommendations of Rangarajan committee to initiate automation in banking operations.

The IT Act of 2000 of Govt. of India provided a legal recognition to electronic banking transactions with RBI establishing a work-group to supervise and monitor issues such as security and technology, legal and control and supervision. Automated banking, for a considerable period of time, was an activity constrained to the metros and big cities in India. Phenomenal penetration of technologies and its convergence paved the path for banking service automation in semi-urban and rural areas of India also. The probable two behavioural consequences of service quality, which are factor-prime for service organizations like banks are customer loyalty and propensity to switch because both these phenomenon are linked to profitability. With the competition becoming fierce, customer loyalty and favourable behavioural consequences have emerged as two potential defensive tools for the banks. The recent adoption of Customer Relationship Management (CRM) as a business philosophy saw the banks developing better proactive strategies to ensure better personalization and customization of service delivery.

This paper attempts to explore the probable impacts of automated service quality on behavioural intentions of customers in a CRM dominated environment of a bank. The rationale behind choosing SBI has been the completion of their decade long modernization and up-scaling of their operation from a legacy dominated silos-based customer transaction to a electronic banking format and being the largest nationalized bank in India its geographical penetration and bank branch networking (availability of services). The organisation of this study following the 'Introduction' has been done as: review of literature, research model and formulation of hypotheses, methodology, data analysis and interpretation and conclusion with limitations of the study and future research prospect.

\section{Review of literature}

Service quality was one of the most critical issues in maintaining sustainable relationship with the customers (Peng \& Wang, 2006). Researchers, over the years, explored and conducted a number of empirical works to understand the nature of service quality, its dimensions and dynamics and probable ways to enhance the perceived service quality (Cronin \& Taylor, 1992, 1994; Rust \& Zahorick, 1993; Avkiran, 1994, Kearns \& Nadler, 1992; Parasuraman et al., 1985, 1988, Julian \& Ramaseshan, 1994, Llosa et al., 1998, Crosby \& Stephens, 1987). Contemporary research works have also highlighted the independent effect of perception on service quality evaluations and have questioned the use of disconfirmation paradigm (Parasuraman et al., 1994, Oliver, 1981) as the basis for the assessment of service quality (Carman, 1990; Bolton \& Drew, 1991a; Babakus \& Boller, 1992, Cronin \& Taylor, 1992).

Grönroos (1982) described service quality as a customer's perception of difference between the expected service and the perceived service. The study of service quality was pioneered by Parasuraman, Zeithaml and Berry (PZB), who developed the gaps framework in 1985 and its related SERVQUAL instrument (Parasuraman et al., 1985, 1988, 1991) whereby five dimensions of service quality were proposed namely tangibles, reliability, responsiveness, assurance and empathy. The transition of service delivery system from employee-customer interaction to employee-technology and technology-customer interactions included a new dimension in service delivery mechanism and 
vis-à-vis perceived service quality (Alkibsi \& Lind, 2011). Technology integration in services has empowered the customers to enjoy a degree of autonomy and has reduced the burden of nonmonetary cost, mainly psychological in nature, to a great extent. Henderson et al. (2003) was of the opinion that automated service provides organisation to introduce new models for service design and development. Ruyter et al (2001) defined automated service as interactive, content-centered and internet-based customer service driven by the customer and integrated with the related organisation customer support process and technologies with the goal of strengthening the customer-service provider relationship. Parasuraman et al. (2005) viewed automated services as web-based services while Buckley (2003) conceptualized automated services as electronic provision of services to a customer. Automated service quality has been identified by Santos (2003) as consumers' evaluation of e-service quality in a virtual market place.

The banking system adopted the automated service delivery process and went one step further to focus on convergence of technologies to provide a customer more than one channel to access in service delivery process. It was argued by Joseph and Stone (2003) that service delivery quality is a critical element in the success of service transactions and to a great extent influence customer satisfaction and retention. Introduction of automated banking services triggered changes in consumer behaviour, consumer perception towards banking service quality, innovation in service delivery system, channel integration, communication and relationship marketing which received adequate emphasis on behalf of the academic researchers (Laforet \& Li, 2005; Gerard \& Cunningham, 2003; Hernandez \& Mazzon, 2007; Wolfinbarger \& Gilly, 2002; Yang et al., 2004, Mukherjee \& Nath, 2003). Banking, which was conventionally a high contact service, the disintermediation with the introduction on technology, was considered to be critical towards establishing quality perception in the minds of the customers (Broderick \& Vachirapornpuk, 2002).

Dhabolkar ((1994) argued that the automated channels made customer participation in service delivery process more intense. A number of researchers considered ATM, internet banking, telephone/mobile banking as the principal automated service delivery channels (Dabholkar, 1994; Meuter et al., 2000; Szymanski \& Hsiech, 2006; Radecki et al., 1997). Dabholkar (1996) concluded that these three major electronic/automated service channels were frequently accessed by the bank customers in combination with each other, which was further considered to be a relationship-building platform (Lans \& Colgate, 2003; Patricio et al., 2003; Ramsay \& Smith, 1999). In a comparatively recent study Lin and Hsiech (2006) investigated factors that affect customers' perception of service quality within the domain of self-service technologies and identified seven dimensions of automated service quality - functionality, enjoyment, security, assurance, design, convenience and customization. Quite a few researchers explored automated service quality dimensions and subsequently developed models to assess service quality such as SITEQUAL (Yu \& Donthu, 2001), WEBQUAL (Loiacono et al., 2002), eTailQ (Wolfinbarger \& Gilly, 2002), E-SERVQUAL (Zeithaml, et al., 2005) SSTQUAL (Lin \& Hsiech, 2006). Al Hawari et al. (2005) developed the concept of Automated Service Quality Index (ASQI) by highlighting five factors - ATM service quality, telephone banking, internet banking services, core service quality and customer perception of service quality.

In a study conducted by Al Hawari and Ward (2006), it was concluded that the three major automated service channels used by the banks to deliver services are significantly related to customer retention thereby providing the researcher cues to conclude a possible behavioural intention link to automated service quality. In a study conducted by Hanzaee and Sadeghi (2010) it was observed that accuracy, reliability, image, impression of the bank management and website design were significantly correlated to customer satisfaction. 
Superior service quality leads to favorable behavioral intentions, leading to retention and subsequent generation of revenue, increased spending, payment of price premiums, and generation of referred customers (Zeithaml et al., 1996). Excellent service is a profit strategy because the results include new customers, increased business with existing customers, fewer lost customers, more cushioning from price competition and fewer mistakes requiring the services to be repeated (Berry et al., 1994). Listening to the customer is a part of providing excellent service. Inferior service quality leads to unfavorable behavioral intentions, which lead to customer defection from the organization which leads to decreased spending, lost customers, and increasing costs associated with attracting new customers (Zeithaml et al., 1996).

Customer switching behavior can damage market share and profitability. Switching can cost an organization the customer's future revenue stream (Keaveney, 1995). Evidence that customer loyalty makes an organization more profitable makes it imperative that complaints and other unfavorable behavioral intentions are handled effectively to ensure the stability of these relationships (Tax \& Brown 1998a). Managers of service firms should know that some customers would switch services even when they are satisfied with a former provider (Keaveney, 1995).

Zeithaml et al. (1996) highlighted the behavioural consequences of service quality and proposed a comprehensive, multi-dimensional framework of customer behavioural intentions, nomenclated as Behavioural Intentions Battery (BIB), to be used in the service industry. The framework consists of 13-items across five dimensions namely loyalty to organisation, propensity to switch, willingness to pay more, external responses to a problem and internal responses to a problem.

The automation of bank's operational aspects was not restricted to technological upgradation alone as it paved way for a novel business philosophy - Customer Relationship Management (CRM). Customer Relationship Management (CRM), defined by Nguyen et al. (2007), is an information system that enables organizations to track customers' interactions with their firms and allows employees to extract customer-based information namely history of sales, unresolved problems, payment records, service records etc. Customer Relationship Management (CRM) has been argued to replace the traditional 4Ps of marketing (product, price, place and promotion) concept as a dominant logic in marketing process (Gurau, 2003) and refers to all business activities directed towards initiating, establishing, maintaining, and developing successful long-term relational exchanges (Heide, 1994; Reinartz \& Kumar, 2003).

Gradual polarization of marketing process towards a relationship base was found to be more effective in establishing mutually profit-benefit transactions between sellers and buyers respectively. The scholastic debate sprung a number of views about the domain of CRM - some researchers view CRM as a mere software based application, therefore emphasizing on the process part; while others consider CRM as a philosophy which aims to translate customer intimacy into profit (Yueh et al., 2010, Soon, 2007; Nguyen et al., 2007 \& Eric et al., 2006).

Subsequent research works have highlighted CRM as an integration of people, process and technology, targeted to bring firms closer to customers. Reynolds (2002) identified three key processes, which brought companies closer to customers and vice-versa: data-enabling productcentric processes, customer-centric processes and one-to-one philosophy. Empirical research works pointed out, time and again, towards the mutual and symbiotic benefits both for the sellers and customers (Dekimpe et al., 1997). In a study Gray and Byun (2001) viewed CRM as a continuous flow of corporate changes in culture and processes that combines three focal areas: (i) Customer (ii) Relationship and (iii) Management. Richard Barrington (2008) viewed that CRM systems evolved as a system to track customer interactions with an objective to offer customized products and services to the customer. 
With this introduction of hyper-customized products and services, particularly in the cross-selling and up-selling domains of a financial service organization, the customer needs and desires have undergone a sea change. CRM Guru (2006) conducted a study, which was subsequently reported by Sandall (2007), with regard to this growing complexity in customer need identification. GrabnerKraeuter and Moedritscher (2002) point to the lack of an adequate CRM strategic framework from which to define success as being a reason for the disappointing results of many CRM initiatives. One of the major reasons for CRM failing to deliver goods is overemphasis on technological aspect by ignoring the 'people' and the process part. Buttle (2001) provides a CRM value chain.

One of the results of CRM is the promotion of customer loyalty (Evans \& Laskin, 1994), which is considered to be a relational phenomenon (Chow \& Holden, 1997; Jacoby \& Kyner, 1973; Sheth \& Parvatiyar, 1995; Macintosh \& Lockshin, 1997). The benefits of customer loyalty to a provider of either services or products are numerous, and thus organizations are eager to secure as significant a loyal customer base as possible (Gefen, 2002; Reinartz \& Kumar, 2003; Rowley \& Dawes, 2000).

The idea that one cannot have a profitable relationship with all customers and the practice of targeting customers with a differentiated product or service is already widespread in many financial services, e.g. banking, insurance, credit cards etc. Review of literature revealed that while academic research works were carried out substantially to identify the dimensions of automated service quality, not much of emphasis was given to explore the probable linkage between perceived automated service quality and behavioural consequences of customers in a CRM dominated business environment.

\section{Research model and formulation of hypotheses}

Based on the review of literature this paper attempts empirically to explore possible linkages between perceived automated service quality (PASQ), customer satisfaction (CS) and behavioural intentions (BI) for bank customers in a Customer Relationship Management (CRM) environment. The proposed research model is depicted in Fig. 1 below:

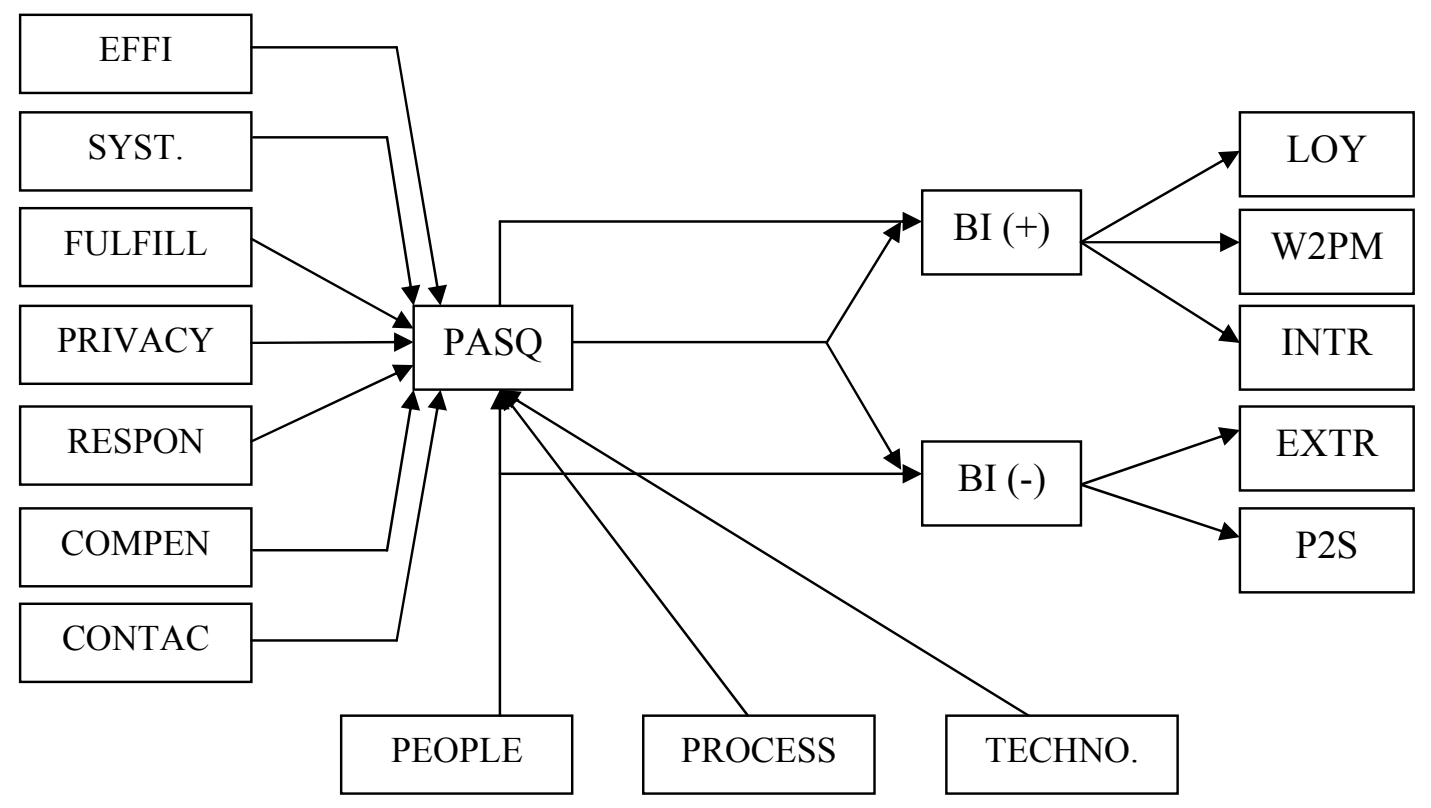

Fig.1. The research model

Accordingly it is hypothesized that: 
$\mathrm{H}_{1}$ : Behavioural intention (BI) is dependent on perceived automated service quality (PASQ).

$\mathrm{H}_{01}$ : Behavioural intention (BI) is independent of perceived automated service quality (PASQ).

$\mathrm{H}_{2}$ : Perceived automated service quality (PASQ) is influenced by CRM components

$\mathrm{H}_{02}$ : Perceived automated service quality (PASQ) is uninfluenced by CRM components

$\mathrm{H}_{3}$ : Customer loyalty is influenced by perceived automated service quality (PASQ).

$\mathrm{H}_{03}$ : Customer loyalty is uninfluenced by perceived automated service quality (PASQ).

$\mathrm{H}_{4}$ : Propensity to switch is influenced by perceived automated service quality (PASQ).

$\mathrm{H}_{04}$ : Propensity to switch is uninfluenced by perceived automated service quality (PASQ).

\section{Methodology}

The objectives of this study were to investigate the impact of automated service delivery channels (perceived automated service quality) on behavioural intentions (BI) of customers, to suggest a model to fit the relationship using SEM approach and to identify the nature of relationship between the variables using Causal Loop Diagramming (CLD). The study was conducted in two phases. To carry out this study, State Bank of India (SBI), the largest nationalized public sector bank in India was selected primarily because of its intensive branch network (availability of services), its upgradation to digitized platform towards service delivery and its adoption of CRM philosophy.

A structured questionnaire was developed to obtain the primary data. The questionnaire had four sections. Section-I asked questions about customers' perception of automated service quality, sectionII dealt with placing questions with regard to behavioural intentions of the customers, section-III targeted customer response in context with CRM components and their performance and section-IV attempted to collect the demographic profile of the customers.

E-SERVQUAL scale developed by Zeithaml, Parasuraman and Malhotra (2005) was used to generate response about customers' perception of automated service quality across both the core and recovery dimensions. To obtain response with regard to behavioural intentions of customers as an output to customer satisfaction, the Behavioural Intention Battery (BIB) developed by Zeithaml et al. (1996) was used. The respondents were asked to rate the statements related to automated banking service channels over a 7 point Likert scale (Alkibisi \& Lind, 2011).

The study was carried out in two phases. Phase-I involved a pilot study to refine the test instrument with rectification of question ambiguity, refinement of research protocol and confirmation of scale reliability was given special emphasis (Teijlingen \& Hundley, 2001). 20 respondents representing bank customers, bank employees and academic were included to conduct the pilot study. FGI was administered. Cronbach's $\alpha$ coefficient $(>0.7)$ established scale reliability (Nunnally \& Bernstein, 1994).

The second phase of the study was conducted by using a structured questionnaire which was distributed amongst 1000 SBI bank-customers at Kolkata, West Bengal, randomly selected with every $5^{\text {th }}$ customer leaving the bank premise was selected as sample. 'Usage-of-automated-bankingservice' was used as critical-fit criteria while selecting samples. A total number of 712 usable responses were generated with a response rate of $71.20 \%$.

Exploratory factor analysis (EFA) was employed using principal axis factoring procedure with orthogonal rotation through VARIMAX process with an objective to understand the factor 
loadings/cross loadings across components. Cronbach's $\alpha$ was obtained to test the reliability of the data, Kaiser-Meyer-Olkin (KMO) was done for sample adequacy and Barlett's sphericity test was conducted. Structural equation modeling approach using Lisrel 8.80 was used to test the research model.

\section{Data analysis and interpretation}

The demographic data obtained were tabulated in Table 1.

Table 1

Demographic data of the respondents

\begin{tabular}{llll}
\hline Demographic Variables & Factors & Frequency & $\%$ \\
\hline \multirow{2}{*}{ Gender } & Male & 497 & $69.80 \%$ \\
& Female & 215 & $30.20 \%$ \\
\hline \multirow{5}{*}{ Age } & $\leq 21$ years & 32 & $4.49 \%$ \\
& $22-32$ years & 321 & $45.08 \%$ \\
& $33-43$ years & 216 & $30.34 \%$ \\
& $44-54$ years & 68 & $9.55 \%$ \\
\cline { 2 - 2 } Income & $\geq 55$ years & 75 & $10.54 \%$ \\
\hline \multirow{5}{*}{ Occupation } & $\leq$ Rs. 14999.00 & 10 & $1.40 \%$ \\
& Rs. 15000-Rs. 24999.00 & 247 & $34.69 \%$ \\
& Rs. 25000-Rs. 44999.00 & 367 & $51.54 \%$ \\
& $\geq$ Rs. 45000.00 & 88 & $12.37 \%$ \\
\hline & Service [govt./prv] & 399 & $56.03 \%$ \\
& Self employed & 132 & $18.54 \%$ \\
& Professionals & 65 & $9.13 \%$ \\
\hline \multirow{5}{*}{ Educational qualification } & Student & 23 & $3.23 \%$ \\
& Housewives & 57 & $8.00 \%$ \\
& Others [retd., VRS etc] & 36 & $5.07 \%$ \\
\hline & High school & 3 & $0.43 \%$ \\
& Graduate & 472 & $66.29 \%$ \\
& Postgraduate & 205 & $28.79 \%$ \\
& Doctorate \& others (CA, fellow etc) & 32 & $4.49 \%$ \\
\hline & & &
\end{tabular}

Table 2 represents the rotated component matrix following the exploratory factor analysis. The Cronbach's $\alpha$ value for all the measures (except three items of core E-SQUAL namely 'the site enables me to get on to it quickly', 'the site makes items available for delivery within a suitable time frame, 'it has in-stock the items the company claims to have' and for the five items of recovery ESQUAL namely 'the site compensates me for problems it creates', 'it compensates me when what I ordered does not arrive on time', 'it picks up items I want to return from my home or business', 'the site offers a meaningful guarantee' and 'it offers the ability to speak to alive person if there is a problem') exceeded the minimum standard of .7 (Nunnally and Bernstein, 1994) suggesting and confirming about the reliability of the measures. The items which were loaded with a lesser value to .7 were subsequently deleted. 
Table 2

Rotated component matrix and Reliability statistics

\begin{tabular}{|c|c|c|c|c|c|c|c|}
\hline \multirow{2}{*}{ Variable } & \multirow{2}{*}{ Variable statement } & \multicolumn{6}{|l|}{ Factors } \\
\hline & & F1 & $\mathrm{F} 2$ & F3 & F4 & F5 & F6 \\
\hline V1 & $\begin{array}{l}\text { SBI's websites makes it easy to search what } \\
\text { is required }\end{array}$ & .821 & & & & & \\
\hline $\mathrm{V} 2$ & Navigation is smooth in the SBI's websites & .867 & & & & & \\
\hline V3 & Page download is fast & .768 & & & & & \\
\hline V4 & $\begin{array}{l}\text { Transaction takes place in real-time and does } \\
\text { not freeze before completion }\end{array}$ & .712 & & & & & \\
\hline V5 & $\begin{array}{l}\text { Information are well displayed in Banks' } \\
\text { websites }\end{array}$ & .855 & & & & & \\
\hline V6 & SBI's web-services are simple to use & .871 & & & & & \\
\hline V7 & $\begin{array}{l}\text { SBI's websites are always available for } \\
\text { transaction }\end{array}$ & & 0.823 & & & & \\
\hline V8 & SBI's websites launch and run right away & & 0.811 & & & & \\
\hline V9 & SBI's website does not crash & & 0.798 & & & & \\
\hline V10 & $\begin{array}{l}\text { Pages in SBI's websites do not freeze while } \\
\text { transaction is on }\end{array}$ & & 0.875 & & & & \\
\hline V11 & $\begin{array}{l}\text { SBI's website deliver services when } \\
\text { promised }\end{array}$ & & & 0.841 & & & \\
\hline V12 & SBI's websites promptly delivers services & & & 0.824 & & & \\
\hline V13 & $\begin{array}{l}\text { SBI's websites are truthful about their } \\
\text { offerings }\end{array}$ & & & 0.819 & & & \\
\hline V14 & $\begin{array}{l}\text { SBI website's make accurate promises about } \\
\text { transactions }\end{array}$ & & & 0.809 & & & \\
\hline V15 & $\begin{array}{l}\text { SBI's provides financial security and } \\
\text { confidentiality }\end{array}$ & & & & .921 & & \\
\hline V16 & $\begin{array}{l}\text { Web-interface is secured with virtual } \\
\text { keyboard set-up for logging in }\end{array}$ & & & & .911 & & \\
\hline V17 & $\begin{array}{l}\text { SBI's websites can be trusted against misuse } \\
\text { of information of transaction details }\end{array}$ & & & & .807 & & \\
\hline V18 & $\begin{array}{l}\text { SBI's websites can be trusted against } \\
\text { mishandling of personal information stored }\end{array}$ & & & & .739 & & \\
\hline V19 & $\begin{array}{l}\text { SBI's websites provide convenient options } \\
\text { for cancelling transactions }\end{array}$ & & & & & .768 & \\
\hline $\mathrm{V} 20$ & $\begin{array}{l}\text { SBI's websites deals well with cancelation } \\
\text { of transactions }\end{array}$ & & & & & .717 & \\
\hline V21 & $\begin{array}{l}\text { SBI's websites guide me in case of } \\
\text { transactions not being processed }\end{array}$ & & & & & .784 & \\
\hline $\mathrm{V} 22$ & $\begin{array}{l}\text { SBI's web-service takes care of problems } \\
\text { promptly }\end{array}$ & & & & & .754 & \\
\hline V23 & $\begin{array}{l}\text { SBI's web-service has customer } \\
\text { representative who shows willingness to }\end{array}$ & & & & & & .789 \\
\hline V24 & $\begin{array}{l}\text { SBI's websites provide a valid telephone } \\
\text { number to contact the bank when required }\end{array}$ & & & & & & .694 \\
\hline V25 & $\begin{array}{l}\text { SBI's website offers the facility to speak live } \\
\text { to an authorized service if there is a problem }\end{array}$ & & & & & & .712 \\
\hline & Cronbach's $\alpha$ & 0.926 & 0.891 & 0.889 & 0.871 & 0.859 & 0.912 \\
\hline & KMO measure for sampling adequacy & & & & & & \\
\hline & Initial eigen values & 4.262 & 3.644 & 2.497 & 2.308 & 1.979 & 1.211 \\
\hline & $\%$ of variance & 18.472 & 12.671 & 9.333 & 9.067 & 8.337 & 6.813 \\
\hline & Cumulative \% & 18.472 & 31.413 & 40.746 & 49.813 & 58.150 & 64.963 \\
\hline
\end{tabular}


The initial 33 variables (including both core and recovery items of E-SERVQUAL) were reduced to 25 variables with variables having factor loading scores of $<0.7$ were discarded. The variables were grouped into six dimensions according to the factor loading scores and were nomenclated as in Table-

3.

\section{Table 3}

Dimensions

\begin{tabular}{cc}
\hline Variables & Dimension \\
\hline V1-V6 & Efficiency \\
V7-V10 & Web-System \\
V11-V14 & Commitment \\
V15-V18 & Security \\
V19-V22 & Responsiveness \\
V23-V25 & Contact \\
\hline
\end{tabular}

To test the relationship between perceived automated service quality (PASQ) and the core \& recovery dimensions of modified E-SERVQUAL bivariate correlation was applied to understand the correlation between the variables. The results of correlation analysis have been displayed in Table- 4 . The PASQ score was obtained by calculating the mean of response for an individual respondent over a 7 point Likert scale across all the items of E-SERVQUAL scale.

Table 4

Bivariate correlation between perceived automated service quality and dimensions of E-SERVQUAL

\begin{tabular}{|c|c|c|c|c|c|c|c|c|}
\hline & & PASQ & Efficiency & Com & Security & Res & Contact & Web \\
\hline \multirow{3}{*}{ PASQ } & Pearson Correlation & 1.000 & $.205^{* *}$ & $.924^{* *}$ & $.125^{* *}$ & $.220^{* *}$ & $.209^{* *}$ & $.506^{* *}$ \\
\hline & Sig. (2-tailed) & & .000 & .000 & .004 & .000 & .000 & .000 \\
\hline & $\mathrm{N}$ & 528 & 528 & 528 & 528 & 528 & 528 & 528 \\
\hline \multirow{3}{*}{ Efficiency } & Pearson Correlation & $.205^{* *}$ & 1.000 & $.241^{* *}$ & -.032 & $.500^{* *}$ & $.461^{* *}$ & $.166^{* *}$ \\
\hline & Sig. (2-tailed) & .000 & & .000 & .467 & .000 & .000 & .000 \\
\hline & $\mathrm{N}$ & 528 & 528 & 528 & 528 & 528 & 528 & 528 \\
\hline \multirow{3}{*}{ Com } & Pearson Correlation & $.924^{* *}$ & $.241^{* *}$ & 1.000 & $.088^{*}$ & $.195^{* *}$ & $.190^{* *}$ & $.513^{* *}$ \\
\hline & Sig. (2-tailed) & .000 & .000 & & .043 & .000 & .000 & .000 \\
\hline & $\mathrm{N}$ & 528 & 528 & 528 & 528 & 528 & 528 & 528 \\
\hline \multirow{3}{*}{ Security } & Pearson Correlation & $.125^{* *}$ & -.032 & $.088^{*}$ & 1.000 & $.162^{* *}$ & -.055 & $.557^{* *}$ \\
\hline & Sig. (2-tailed) & .004 & .467 & .043 & & .000 & .209 & .000 \\
\hline & $\mathrm{N}$ & 528 & 528 & 528 & 528 & 528 & 528 & 528 \\
\hline \multirow{3}{*}{ Res } & Pearson Correlation & $.220^{* *}$ & $.500^{* *}$ & $.195^{* *}$ & $.162^{* *}$ & 1.000 & $.353^{* *}$ & $.247^{* *}$ \\
\hline & Sig. (2-tailed) & .000 & .000 & .000 & .000 & & .000 & .000 \\
\hline & $\mathrm{N}$ & 528 & 528 & 528 & 528 & 528 & 528 & 528 \\
\hline \multirow{3}{*}{ Contact } & Pearson Correlation & $.209^{* *}$ & $.461^{* *}$ & $.190^{* *}$ & -.055 & $.353^{* *}$ & 1.000 & $.168^{* *}$ \\
\hline & Sig. (2-tailed) & .000 & .000 & .000 & .209 & .000 & & .000 \\
\hline & $\mathrm{N}$ & 528 & 528 & 528 & 528 & 528 & 528 & 528 \\
\hline \multirow{3}{*}{ Web } & Pearson Correlation & $.506^{* *}$ & $.166^{* *}$ & $.513^{* *}$ & $.557^{* *}$ & $.247^{* *}$ & $.168^{* *}$ & 1.000 \\
\hline & Sig. (2-tailed) & .000 & .000 & .000 & .000 & .000 & .000 & \\
\hline & $\mathrm{N}$ & 528 & 528 & 528 & 528 & 528 & 528 & 528 \\
\hline
\end{tabular}


The results of correlation analysis (Table-4) exhibited a strong and positive correlation between perceived automated service quality (PASQ) and the core E-SERVQUAL dimensions namely efficiency $\left(\mathrm{r}=.205^{* *}, \mathrm{p}<.001\right)$, commitment $\left(\mathrm{r}=.924^{* *}, \mathrm{p}<.001\right)$, security $\left(\mathrm{r}=.125^{* *}, \mathrm{p}<.005\right)$ and websystem $\left(\mathrm{r}=.506^{* *}, \mathrm{p}<.001\right)$ suggesting significance of the dimensions in perceiving the automated service quality. It was further established that a strong and positive relationship between the recovery dimensions of automated service quality and responsiveness $\left(\mathrm{r}=.220^{* *}, \mathrm{p}<.001\right)$ and contact $(\mathrm{r}=.209 * *, \mathrm{p}<.001)$ exist which is indicative of significance of recovery dimensions towards perceiving automated service quality.

The Behavioural Intention Battery (Zeithaml et al., 1996) was used to obtain the behavioural intention scores of the respondents across five dimensions (13 items) of the same namely loyalty, will-to-pay-more, internal response (positive behavioural intention indicators) and propensity-toswitch and external response (negative behavioural intention indicators). Correlation matrix (Table-5) revealed that perceived automated service quality (PASQ) had a strong and positive relationship with loyalty $\left(\mathrm{r}=.634^{* *}, \mathrm{p}<.001\right)$, will-to-pay-more $(\mathrm{r}=.509 * *, \mathrm{p}<.001)$ and internal response $(\mathrm{r}=.491 * *$, $\mathrm{p}<.001)$ while PASQ revealed a negative relationship with propensity-to-switch $\left(\mathrm{r}=-.141^{*}, \mathrm{p}<.005\right)$ indicating that customers with higher and better perceived automated service quality with regard to their bank (SBI) tend to exhibit positive behavioural intentions. Perceived automated service quality did not exhibit a significant relationship with external response.

\section{Table 5}

Correlation matrix between perceived automated service quality (PASQ) and behavioural intention (BI) dimensions

\begin{tabular}{|c|c|c|c|c|c|c|c|}
\hline & & PASQ & Loyalty & Will2paymore & Propensity2switch & Externalresponse & Internalresponse \\
\hline \multirow{3}{*}{ PASQ } & Pearson Correlation & 1.000 & $.634^{* *}$ & $.509^{* *}$ & $-.141^{*}$ & .065 & $.491^{* *}$ \\
\hline & Sig. (2-tailed) & & .000 & .000 & .003 & .448 & .000 \\
\hline & $\mathrm{N}$ & 528 & 528 & 528 & 528 & 528 & 528 \\
\hline \multirow{3}{*}{ Loyalty } & Pearson Correlation & $.634^{* *}$ & 1.000 & -.045 & .079 & .020 & $.744^{* *}$ \\
\hline & Sig. (2-tailed) & .000 & & .304 & .069 & .653 & .000 \\
\hline & $\mathrm{N}$ & 528 & 528 & 528 & 528 & 528 & 528 \\
\hline \multirow{3}{*}{ Will2paymore } & Pearson Correlation & $.509^{* *}$ & -.045 & 1.000 & $-.111^{*}$ & .062 & .010 \\
\hline & Sig. (2-tailed) & .000 & .304 & & .011 & .158 & .812 \\
\hline & $\mathrm{N}$ & 528 & 528 & 528 & 528 & 528 & 528 \\
\hline \multirow{3}{*}{ Propensity2switch } & Pearson Correlation & $-.141^{*}$ & .079 & $-.111^{*}$ & 1.000 & $-.105^{*}$ & $.109^{*}$ \\
\hline & Sig. (2-tailed) & .003 & .069 & .011 & & .016 & .012 \\
\hline & $\mathrm{N}$ & 528 & 528 & 528 & 528 & 528 & 528 \\
\hline \multirow{3}{*}{ Externalresponse } & Pearson Correlation & .065 & .020 & .062 & $-.105^{*}$ & 1.000 & .057 \\
\hline & Sig. (2-tailed) & .448 & .653 & .158 & .016 & & .188 \\
\hline & $\mathrm{N}$ & 528 & 528 & 528 & 528 & 528 & 528 \\
\hline \multirow{3}{*}{ Internalresponse } & Pearson Correlation & $.491^{* *}$ & $.744^{* *}$ & .010 & $.109^{*}$ & .057 & 1.000 \\
\hline & Sig. (2-tailed) & .000 & .000 & .812 & .012 & .188 & \\
\hline & $\mathrm{N}$ & 528 & 528 & 528 & 528 & 528 & 528 \\
\hline
\end{tabular}

**Correlation is significant at 0.01 level (2-tailed), ${ }^{*}$ Correlation is significant at 0.05 level (2-tailed)

The Pearson ' $r$ ' correlation coefficient suggested that the PASQ level of customers about State Bank of India is indicating customers' likelihood to remain associate with the bank in future, on the basis of significant correlationship with 'loyalty' and 'willing to pay more' dimensions of BIB. Further to this the respondents demonstrated confidence in the bankers (internal response) when faced with a problem. 
To have a better understanding of relationship of loyalty and propensity to switch with perceived automated service quality, regression analysis was applied. The results of the same were represented in Table- 6 and Table-7. The model summary of regression between PASQ and loyalty exhibited $\mathrm{R}^{2}$ and adjusted $\mathrm{R}^{2}$ (Table-6) to be as .357 and .356 indicating that perceived automated service quality (PASQ-independent variable) measures $35.70 \%$ of the variation in loyalty (dependent variable) which is considered to be significant enough for predictability of the model. The regression results between PASQ and propensity-to-switch displayed $\mathrm{R}^{2}$ (Table-7) and adjusted $\mathrm{R}^{2}$ as .190 and .188 respectively affirming 19\% measure of variation. ANOVA (Table-6 and Table-7) established that the variation showed by the perceived automated service quality was significant at $1 \%$ level $(\mathrm{f}=31.874, \mathrm{p}<.001$ and $\mathrm{f}=19.611, \mathrm{p}<.001)$. Regression coefficients (Table-6) confirmed a strong and positive associationship between perceived automated service quality and loyalty $(\beta=.597, \mathrm{t}=9.082, \mathrm{p}<.001)$. Regression coefficients (Table-7) exhibited a significant but negative relationship between perceived automated service quality and propensity-to-switch $(\beta=.143, \mathrm{t}=3.616, \mathrm{p}<.001)$.

Table 6

Regression results between PASQ and Loyalty

\begin{tabular}{llllllll}
\hline \multicolumn{2}{l}{ Model Summary } & \multicolumn{3}{c}{ ANOVA } & \multicolumn{3}{c}{ Regression coefficients } \\
\hline $\mathrm{R}$ & $\mathrm{R}^{2}$ & adjusted $\mathrm{R}^{2}$ & $\mathrm{~F}$ & $\mathrm{Sig}$ & $\beta$ & $\mathrm{t}$ & sig. \\
\hline .598 & .357 & .356 & 31.874 & .000 & .597 & 9.082 & .000 \\
\hline a. Predictor: Perceived automated service quality (PASQ), b. Dependent variable: Loyalty & &
\end{tabular}

Table 7

Regression results between PASQ and Propensity-to-switch

\begin{tabular}{llllllll}
\hline \multicolumn{3}{l}{ Model Summary } & \multicolumn{3}{c}{ ANOVA } & \multicolumn{3}{c}{ Regression coefficients } \\
\hline $\mathrm{R}$ & $\mathrm{R}^{2}$ & adjusted $\mathrm{R}^{2}$ & $\mathrm{~F}$ & $\mathrm{Sig}$ & $\beta$ & $\mathrm{t}$ & sig. \\
\hline .436 & .190 & .188 & 19.611 & .000 & .143 & 3.616 & .000 \\
\hline $\begin{array}{l}\text { a. Predictor: Perceived automated service quality (PASQ) } \\
\text { b. Dependent variable: Propensity-to-switch }\end{array}$
\end{tabular}

Successful implementation of CRM requires the proper implementation of people, process and technology mix. These are the three key areas that touch the customer. The CRM Score is taken on the three touch-points, the CRM-components: People, Process \& Technology (Table-8). A 7 point Likert scale was used to obtain the response from the respondents about the performance of the three CRM components.

Table 8

CRM components

\begin{tabular}{|c|c|c|}
\hline \multirow[t]{2}{*}{ People } & Empathy & $\begin{array}{l}\text { 1. Individual attention to customers } \\
\text { 2. Understands specific need of customers } \\
\text { 3. Employees have customers' best interest at heart }\end{array}$ \\
\hline & Responsiveness & $\begin{array}{l}\text { 1. Employees instill confidence in customers } \\
\text { 2. Employees deals with public situation carefully }\end{array}$ \\
\hline \multirow{3}{*}{ Process } & SWO [Single Window] & $\begin{array}{l}\text { 1. Ease of in-premise transaction } \\
\text { 2. Assorted service range }\end{array}$ \\
\hline & KYC [Know Your Customer] & $\begin{array}{l}\text { 1. Comprehensive information about customers } \\
\text { 2. Better segmentation of customers } \\
\text { 3. Better understanding of customers' demand }\end{array}$ \\
\hline & MCI Multi-Channel Integration] & $\begin{array}{l}\text { 1. Seamless delivery process } \\
\text { 2. More than one channel to enter into transaction }\end{array}$ \\
\hline \multirow{5}{*}{ Technology } & $\mathrm{CBS}$ & \\
\hline & Mobile technology/Mobile Commerce & \\
\hline & Internet & \\
\hline & Auto Vending Machine [in-premise] & \\
\hline & Digital vigilance system [in-premise] & \\
\hline
\end{tabular}


Multiple regression analysis was performed to assess the strength of associationship between perceived automated service quality (PASQ) and CRM components and predictability of CRM components to predict and determine PASQ. ANOVA (Table-9) result was significant for the model $(\mathrm{f}=42.890, \mathrm{p}<.001)$. Regression coefficient (Table-10) exhibited a strong and positive relationship between PASQ and the CRM components namely people $(\beta=.344, \mathrm{t}=9.258, \mathrm{p}<.001)$, process $(\beta=.356$, $\mathrm{t}=9.979, \mathrm{p}<.001)$ and technology $(\beta=.392, \mathrm{t}=10.567, \mathrm{p}<.001)$. To determine the degree of multicollinearity, the variance inflation factor (VIF) was computed for each independent variable in regression equation. The results (Table-10) suggested that the 'Structural Model for Path Analysis' is worth pursuing as the 'tolerance' value is over 0.200 for each of the independent variable suggesting absence of correlation. The VIF values also did not reveal a considerably high value to 1 confirming non-collinearity as VIF values considerably greater than 1 are indicative of multi-collinearity (Netter et al, 1996) and greater than 2.5 are cause of concern (Allison, 1999) (VIF=1/tolerance).

Table 9

ANOVA results

\begin{tabular}{lllllll}
\hline Model & & Sum of Squares & Df & Mean Square & F & Sig. \\
\hline \multirow{3}{*}{1} & Regression & 16.965 & 3 & 5.655 & 42.890 & $.000^{\mathrm{a}}$ \\
\cline { 2 - 7 } & Residual & 93.350 & 708 & .132 & & \\
\cline { 2 - 7 } & Total & 110.315 & 711 & & & \\
\hline $\begin{array}{l}\text { a. Predictor: People, Process and Technology } \\
\text { b. Dependent variable: PASQ }\end{array}$ & & & &
\end{tabular}

Table 10

Regression coefficients

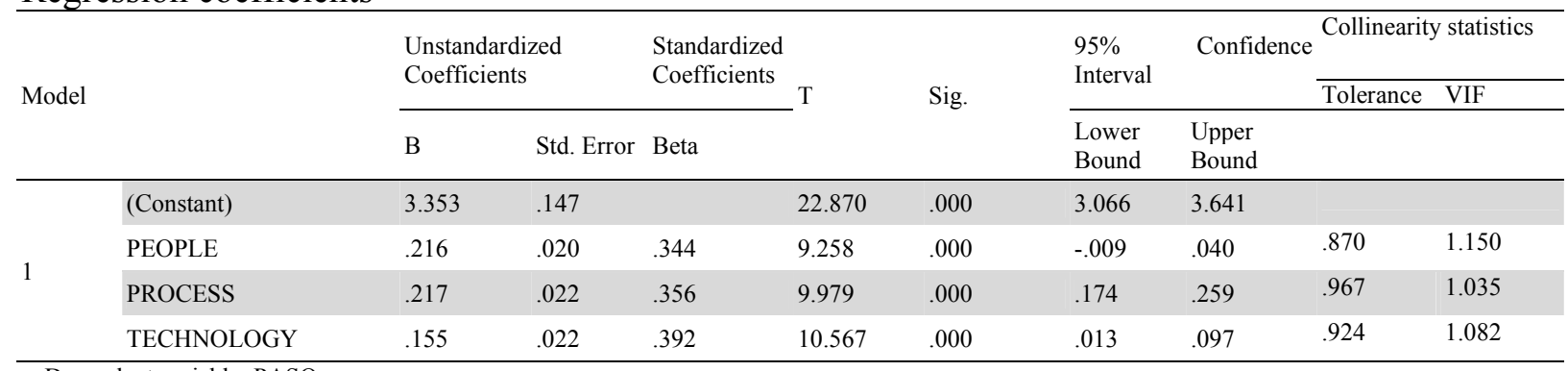

a. Dependent variable: PASQ

Structural equation modeling (SEM) was used to test the nomological validity of the proposed model. E-SERVQUAL, BIB and CRM computation of the scores for the individual dimensions were done by summating the ratings on their individual scale items which were used as indicators of the latent ESERVQUAL, BIB and CRM items. Confirmatory factor analysis was used to understand the dimensionality, convergence and discriminant validity for each construct to determine whether all the 42 indicators (including E-SERVQUAL, BIB and CRM component performance) measure the construct adequately as they had been assigned for. LISREL 8.80 programme was used to conduct the Structural Equation Modeling (SEM) and Maximum Likelihood Estimation (MLE) was applied to estimate the CFA models. A number of fit-statistics (Table-11) were obtained. The GFI, AGFI and NFI scores for all the constructs were found to be consistently $>.900$ indicating that a significant proportion of the variance in the sample variance-covariance matrix is accounted for by the model and a good fit has been achieved (Baumgartner and Homburg, 1996; Hair et al, 1998; Hulland, Chow and Lam, 1996; Kline, 1998; Holmes-Smith, 2002, Byrne, 2001). The CFI value for all the constructs were obtained as $>.900$ which indicated an acceptable fit to the data (Bentler, 1992). The RMSEA values obtained are $<0.08$ for an adequate model fit (Hu and Bentler, 1999). The probability value of Chi-square is more than the conventional 0.05 level $(\mathrm{P}=0.20)$ indicating an absolute fit of the models to the data. The Cronbach's $\alpha$ values were consistently $>.7$ and hence the scale is reliable (Nunnally and Bernstein, 1994). The factor loadings for the items were also significant $(>.500)$. 
Table 11

Summary representation of Confirmatory Factor Analysis (CFA)

\begin{tabular}{|c|c|c|c|c|c|c|c|c|c|c|}
\hline Factor indicators & $\chi^{2}$ & $\mathrm{df}$ & P-value & GFI & AGFI & CFI & NFI & RMSEA & Factor loadings & $\alpha-$ value \\
\hline Efficiency & 8.916 & 5 & 0.081 & 0.971 & 0.961 & 0.981 & 0.979 & 0.062 & & 0.979 \\
\hline EF1 & & & & & & & & & 0.841 & \\
\hline EF2 & & & & & & & & & 0.854 & \\
\hline EF3 & & & & & & & & & 0.876 & \\
\hline EF4 & & & & & & & & & 0.864 & \\
\hline EF5 & & & & & & & & & 0.802 & \\
\hline EF6 & & & & & & & & & 0.771 & \\
\hline EF7 & & & & & & & & & 0.787 & \\
\hline Web-System & 8.541 & 3 & 0.027 & 0.918 & 0.909 & 0.989 & 0.967 & 0.032 & & 0.936 \\
\hline WS1 & & & & & & & & & 0.819 & \\
\hline WS2 & & & & & & & & & 0.797 & \\
\hline WS3 & & & & & & & & & 0.801 & \\
\hline WS4 & & & & & & & & & 0.779 & \\
\hline Commitment & 9.195 & 4 & 0.139 & 0.977 & 0.943 & 0.987 & 0.971 & 0.076 & & 0.941 \\
\hline COM1 & & & & & & & & & 0.818 & \\
\hline COM2 & & & & & & & & & 0.794 & \\
\hline COM3 & & & & & & & & & 0.819 & \\
\hline COM4 & & & & & & & & & 0.766 & \\
\hline COM5 & & & & & & & & & 0.838 & \\
\hline Security & 3.998 & 2 & 0.049 & 0.916 & 0.901 & 0.971 & 0.965 & 0.048 & & 0.832 \\
\hline SEC1 & & & & & & & & & 0.807 & \\
\hline SEC2 & & & & & & & & & 0.791 & \\
\hline SEC3 & & & & & & & & & 0.770 & \\
\hline Responsiveness & 8.197 & 3 & 0.116 & 0.980 & 0.974 & 0.951 & 0.952 & 0.020 & & 0.891 \\
\hline RES1 & & & & & & & & & 0.861 & \\
\hline RES2 & & & & & & & & & 0.865 & \\
\hline RES3 & & & & & & & & & 0.708 & \\
\hline RES4 & & & & & & & & & 0.798 & \\
\hline Contact & 6.375 & 2 & 0.028 & 0.966 & 0.905 & 0.979 & 0.959 & 0.080 & & 0.901 \\
\hline CON1 & & & & & & & & & 0.771 & \\
\hline CON2 & & & & & & & & & 0.779 & \\
\hline Loyalty & 9.219 & 4 & 0.031 & 0.919 & 0.917 & 0.921 & 0.923 & 0.073 & & 0.929 \\
\hline LOY1 & & & & & & & & & 0.881 & \\
\hline LOY2 & & & & & & & & & 0.781 & \\
\hline LOY3 & & & & & & & & & 0.709 & \\
\hline LOY4 & & & & & & & & & 0.817 & \\
\hline LOY4 & & & & & & & & & 0.811 & \\
\hline Will-to-pay-more & 7.891 & 2 & 0.041 & 0.946 & 0.941 & 0.978 & 0.938 & 0.049 & & 0.911 \\
\hline WPM1 & & & & & & & & & 0.791 & \\
\hline WPM2 & & & & & & & & & 0.715 & \\
\hline Internal response & 4.129 & 1 & 0.027 & 0.918 & 0.916 & 0.954 & 0.931 & 0.071 & & 0.891 \\
\hline INTR1 & & & & & & & & & 0.708 & \\
\hline Propensity to switch & 6.871 & 2 & 0.045 & 0.971 & 0.963 & 0.970 & 0.961 & 0.064 & & 0.917 \\
\hline PTS1 & & & & & & & & & 0.866 & \\
\hline PTS2 & & & & & & & & & 0.837 & \\
\hline External response & 8.752 & 3 & 0.069 & 0.955 & 0.943 & 0.959 & 0.967 & 0.049 & & 0.978 \\
\hline EXTR1 & & & & & & & & & 0.792 & \\
\hline EXTR2 & & & & & & & & & 0.811 & \\
\hline EXTR3 & & & & & & & & & 0.781 & \\
\hline CRM & 9.693 & 4 & 0.091 & 0.967 & 0.981 & 0.991 & 0.987 & 0.051 & & 0.997 \\
\hline CRM1 & & & & & & & & & 0.873 & \\
\hline CRM2 & & & & & & & & & 0.859 & \\
\hline CRM3 & & & & & & & & & 0.786 & \\
\hline
\end{tabular}

Structural Equation Modeling (SEM) was used to test the relationship among the constructs. 
A number of fit-indices namely Chi-square $/ \mathrm{df}=1123 / 158, \mathrm{GFI}=0.997, \mathrm{AGFI}=0.969, \mathrm{CFI}=0.981$, $\mathrm{NFI}=0.979$, RMSEA $=0.037$, expected cross validation index $(\mathrm{ECVI})=0.911$ were found to be significant. All the 24 paths drawn were found to be significant at $p<0.05$. The research model holds well (Fig.2) as the fit-indices supported adequately the model fit to the data. The double-curved arrows indicate co-variability of the latent variables. The residual variables (error variances) are indicated by $\epsilon_{1}, \epsilon_{2}, \epsilon_{3}$, etc. The regression weights are represented by $\lambda$. The co-variances are represented by $\beta$. To provide the latent factors an interpretable scale; one factor loading is fixed to 1 (Hox \& Bechger).

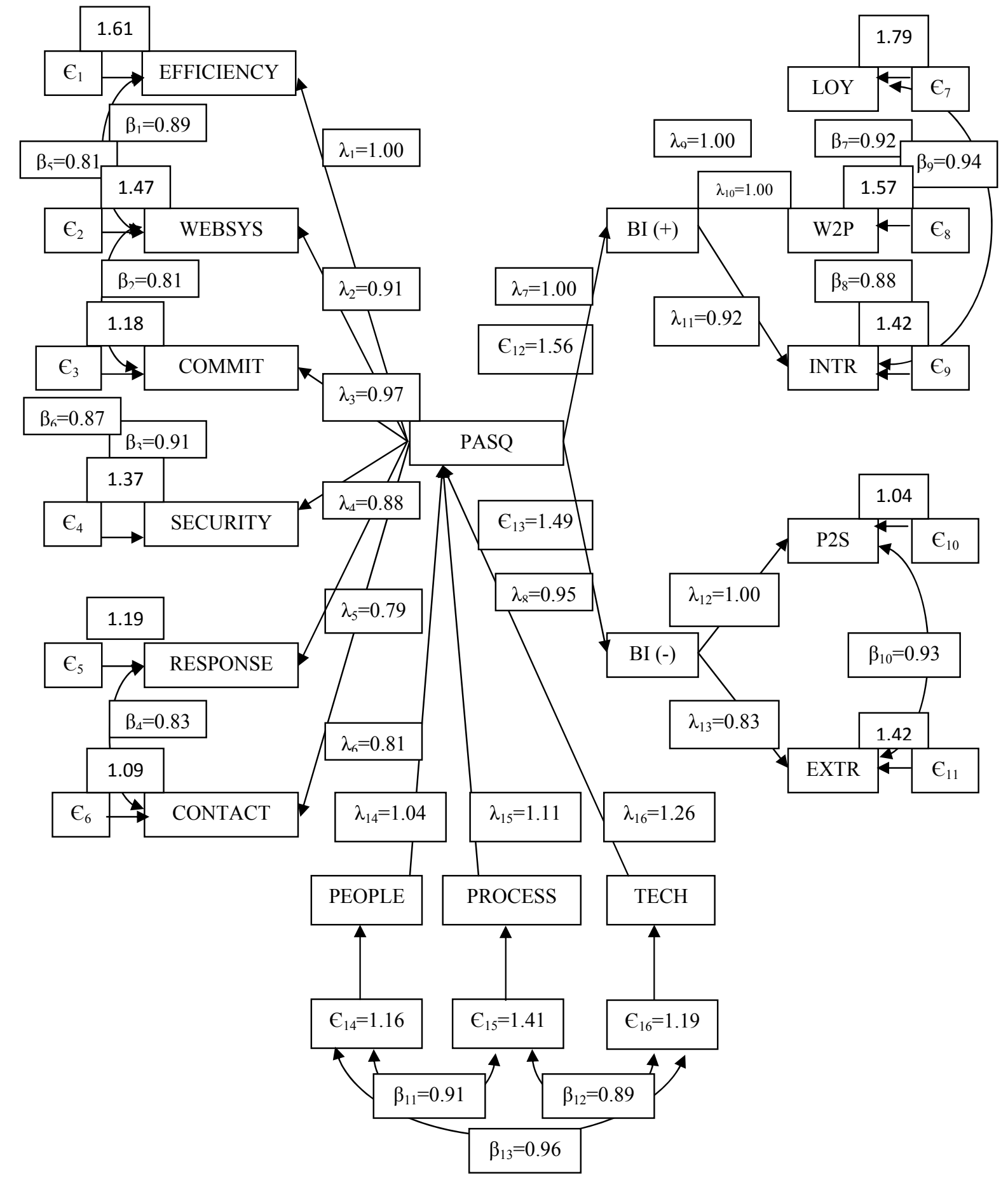

Fig.2. Structural model showing the path analysis using SEM 
A causal loop diagram (CLD) is a diagram that aids in visualizing how interrelated variables affect one another. The diagram consists of a set of nodes representing the variables connected together. The relationships between these variables, represented by arrows, can be labeled as positive or negative. The dynamic causal loop diagramming for the current study may be represented as follows (Fig.3).

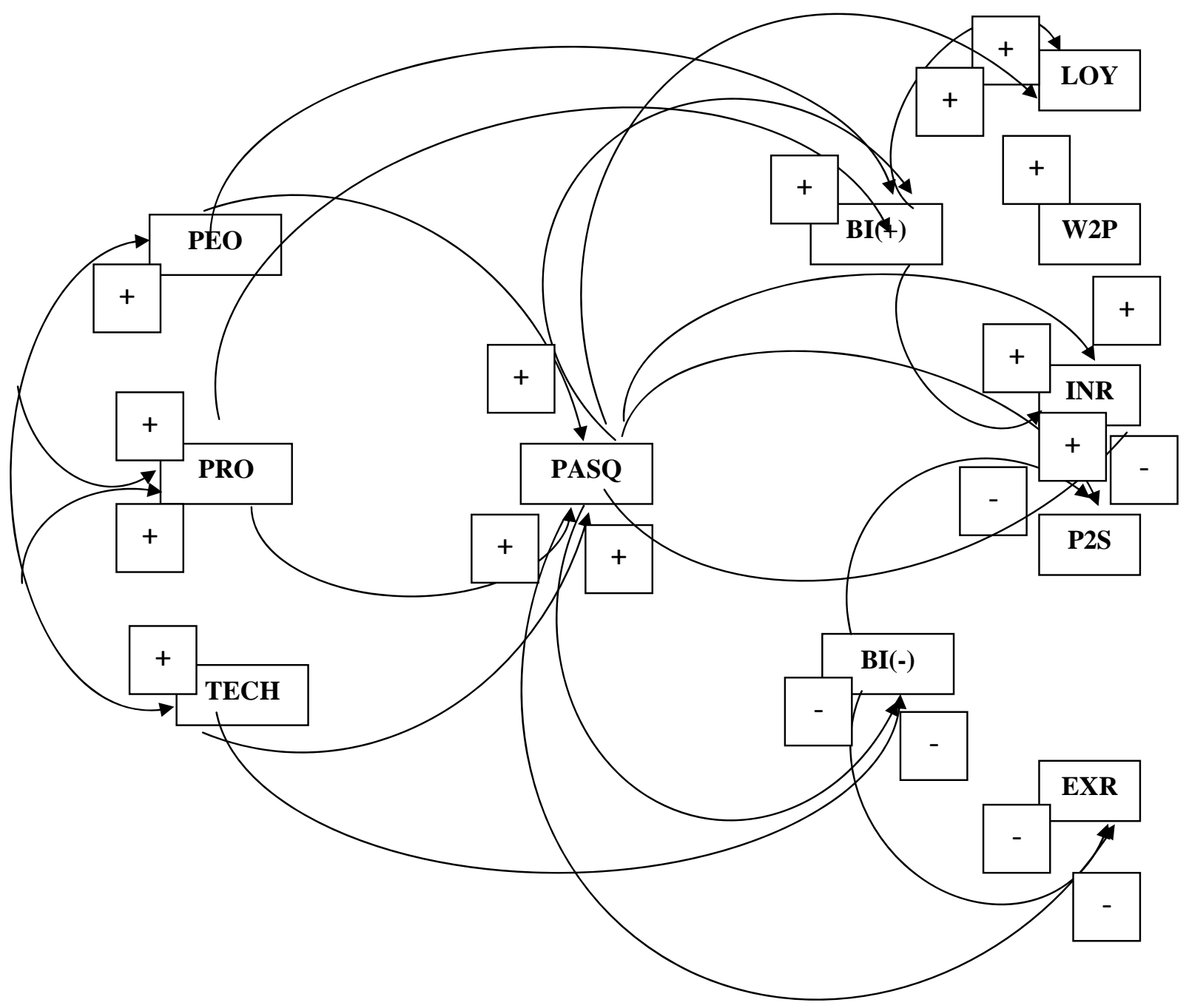

Fig. 3. Causal loop diagramming showing relationship between perceived automated service quality (PASQ), customer relationship management and behavioural intentions (both positive and negative) with its micro-level outputs

\section{Conclusion}

The modernization and automation of State Bank of India (SBI) had been a significant event in the banking industry in India as, being the largest nationalized public sector bank in India, SBI has become the face of Indian electronic banking. The reach and penetration of SBI has been phenomenal and at present due to rapid proliferation of internet services across the length and breadth of the country, the automated (electronic) banking services penetrated the rural geo-demographic domain of India. The core-bank-system of SBI has changed the perception of banking and vis-à-vis quality perception. The study revealed that the automated service quality dimensions which proved to be 
significant in perceiving quality are efficiency, web-system, commitment, security, responsiveness and contact.

The study also confirmed that the customers of SBI had gradually become habituated with automated banking services and are satisfied with the same as it established a strong and positive behavioural intention depicting intentions for loyalty, willing to pay more for services and addressing problems to internal customers only. Behavioural intentions reflected negative attitude towards propensity to switch and lodging external negative canvassing hinting towards customer satisfaction with the automated service quality actually delivered by their bank.

The Customer Relationship Management (CRM) practice initiated by SBI seemed to have properly integrated with their automated operational procedures as the CRM components were found to influence the perceived automated service quality of customers in a positive way. The proposed research model also came through as the model constructs fit the data thereby establishing a cause and effect relationship between the variables and the causal loop diagram effectively exhibited the positive and negative causal relationships between the variables. The study was indicative of the shift and subsequent adoption of automated banking services in a semi-urban/rural set up.

The study had geographical limitations as it has been restricted to Kolkata, West Bengal, which in future, can be widened to obtain a more generalized conclusion. In future the study can be comparative in nature as competition is increasing and there is a strong requirement of service differentiation and customization, whereby service quality between more than one service providers can be chosen effectively. Further to this other intermediating or conclusive variables may be included also for much more elaborative perspectives.

\section{References}

Alkibsi, S., \& Lind, M., (2011). Customer perceptions of technology-based banking service quality provided by banks operating in Yemen. European, Mediterranean \& Middle Eastern Conference on Information Systems 2011 (EMCIS2011) May 30-31 2011, Athens, Greece

Allison, P. D. (1999). Event History Analysis: Regression for Longitudinal Event Data. Newbury Park, CA: Sage Publications, 9-42, [EHA]

Al-hawari, M., Hartley, N., \& Ward, T. (2005), Measuring Banks' Automated Service Quality: A Confirmatory Factor Analysis Approach. Marketing Bulletin, 16(1).

Al-Hawari, M., \& Ward, T. (2006). The effect of automated service quality on Australian banks' financial performance and the mediating role of customer satisfaction. Marketing Intelligence \& Planning, 24( 2), 127-47.

Avkiran, N. K. (1994). Developing an Instrument to Measure Customer Service Quality in Branch Banking. International Journal of Bank Marketing, 12(6), 10-18.

Babakus, E., \& Boller, G.W. (1992). An empirical assessment of the SERVQUAL scale. Journal of Business Research, 24, 253-268.

Baumgartner, H., \& Homburg, C. (1996). Applications of structural equation modeling in marketing and consumer research: A review. International Journal of Research in Marketing, 13, 139-161.

Bentler, P.M. (1992). On the fit of models to covariances and methodology to the Bulletin. Psychological Bulletin, 112(3), 400-404.

Bolton, R., \& Drew, J. (1991a). A longitudinal analysis of the impacts of service changes on customer attitudes. Journal of Marketing, 55(1), 1-9.

Broderick, A.J. \& Vachirapornpuk, S. (2002). Service quality in Internet banking: The importance of customer role. Marketing Intelligence \& Planning, 20(6), 327 - 335.

Buckley, J. (2003). E-service and the public sector. Managing Service Quality, 13(6), 453- 462.

Buttle, F. (2001). The CRM Value Chain". http://www.crm-forum.com (accessed on 19-07-2008) 
Byrne, B. M. (2001). Structural Equation Modeling with AMOS - Basic Concepts, Applications, and Programming.LEA, ISBN 0-8058-4104-0

Carman, J. M. (1990). Consumers' perceptions of service quality: an assessment of the SERVQUAL dimensions. Journal of Retailing, 66(1), 33-55.

CRM Guru (2006). The top five tips for CRM strategy', http://www.crm-guru/the-top-five-tips-forcrm-strategy.php (accessed on 16-07-2008).

Cronin, J., \& Taylor, S.A., (1992). Measuring service quality: A re-examination and extension. Journal of Marketing, 56, 55-67.

Cronin, J., \& Taylor, S. A. (1994). SERVPERF versus SERVQUAL: Reconciling PerformanceBased and Perceptions-Minus-Expectations Measurement of Service Quality. Journal of Marketing, 58, (January), 125-131.

Crosby, L. A., \& Stephens, N. (1987). Effects of relationship marketing on satisfaction, retention, and prices in the life insurance industry. Journal of Marketing Research, 14, 404-11.

Dabholkar, P (1994). Technology based service delivery. Advances in Service Marketing and Management, 3(1), 241-271.

Dabholkar, P. (1996). Consumer evaluations of new technology-based self-service options: An investigation of alternative modes of service quality. International Journal of Research in Marketing. 13(1), 29-51.

Dekimpe, M.G., Steenkamp, J.E.M., Mellens, M., \& Abeele, P.V. (1997). Decline and variability in brand loyalty. International Journal of Research in Marketing, 5(14), 405-20.

Eric, P. J., Tom A. B., \& Charles, E. M. (2006). Operational challenges in call center Industry; a case study and resource based framework. Managing Service Quality Journal, 477-500.

Evans, J. R., \& Laskin, R. L. (1994). The relationship marketing process: A conceptualization and application. Industrial Marketing Management, 23(5), 439-452.

Gefen, D. (2002). Customer loyalty in e-commerce. Journal of the Association for Information Systems, 3, 27-51.

Gerrard, P., \& Cunningham, J.B. (2003). The Diffusion of Internet Banking among Singapore Consumers. International Journal of Bank Marketing, 21(1), 16-28.

Gurau, C. (2003). Tailoring e-service quality through CRM. Journal Managing Service Quality, 13(6), 520-531.

Grabner-Kraeuter, S., \& Moedritscher, G. (2002). Alternative approaches toward measuring CRM performance. Paper presented at the Sixth Research Conference on Relationship Marketing and Customer Relationship Management, Atlanta, USA.

Gray, P., \& Byun, J. (2001). Customer Relationship Management. Centre for Research on Information Technology and Organizations, University of California

Grönroos, C. (1982). Strategic Management and Marketing in the Services Sector. Marketing Science, Cambridge, MA.

Grönroos, C. (1983). Strategic Management and Marketing in the Service Sector. Marketing Science Institute, Boston, MA.

Grönroos, C. (1984). A service quality model and its marketing implications. European Journal of Marketing,18(4), 36-44.

Hair, J.F., Anderson, R.E., Tatham, R.L. and Black, W.C. (1998), 'Multivariate data analysis', $5^{\text {th }}$ edition, Prentice Hall, Upper Saddle, New jersey.

Hanzaee, K.H., \& Sadeghi, T. (2010). Customer satisfaction (CSFs) with online banking services in an Islamic country: I.R. Iran. Journal of Islamic Marketing, 1(3), 249-267.

Heide, J. B. (1994). Interorganizational governance in marketing channels. Journal of Marketing, 58(1), 71-85.

Henderson, J., McGoldrick, E., \& McAdam, R. (2003). A critical review of e-service in Northern Ireland Electricity. Managing Service Quality, 13(6), 463-470.

Hernandez, J.M.C., \& Afonso, M.J. (2007). Adoption of Internet Banking: Proposition and Implementation of an Integrated Methodology Approach. International Journal of Bank 
Management, 25(2), 72-88.

Holmes-Smith, P. (2002). Applied Structural Equation Modeling. Canberra.

Hu, L., \& Bentler, P.M. (1999). Cutoff criteria for fit indexes in covariance structure analysis: conventional criteria versus new alternatives. Structural Equation Modeling, 6(1), 1-55.

Hulland, J., Chow, Y.H., \& Lam, S. (1996). Use of causal models in marketing research: A review. International Journal of Research in Management, 13(2), 181-197.

Hox and Bechger, 'An introduction to structural equation modeling', Family Science Review, 11, pp. 354-373

Jacoby, J., \& Kyner, D.B. (1973). Brand loyalty versus repeat purchase behavior. Journal of Marketing Research, 10(1), 1-9.

Joseph, M \& Stone G. (2003). An empirical evaluation of US bank customer perceptions of the impact of technology in service delivery in the banking sector. International Journal of Retail \& Distribution Management, 31(4), 190-202.

Julian, C. C., \& Ramaseshan, B. (1994). The role of customer-contact personnel in the marketing of a retail bank's services. International Journal of Retail \& Distribution Management, 5, 29-34.

Kearns, D., \& D. Nadler. (1992). Prophets in the Dark: How Xerox Reinvented Itself and Beat Back Japanese. New York: Harper Collins Publishers.

Keaveney, S. M. (1995). Customer switching behavior in service industries: an exploratory study. Journal of Marketing, 59, 71-82.

Khan, M.S., \& Mahapatra, S.S. (2009). Service quality evaluation in internet banking: an empirical study in India. International. Journal Indian Culture and Business Management, 2(1), 30-46.

Kline, R. B. (1998). Principles and practices of structural equation modeling. New York:

Guilford.

Laforet S., \& Li, X. (2005). Consumers' attitude towards online and mobile banking in China. International Journal of Bank Management, 23(5), 362-380.

Lans, B., \& Colgate, M. (2003). Relationship quality, on-line banking and the information technology gap. International Journal of Bank Marketing, 21(1), 29-37.

Lehtinen, J.R., \& Lehtinen, U. (1982). Service quality: a study of quality dimensions. Unpublished working paper, Service Management Institute, Helsinki .

Lin, J.S.C., \& Hsieh, P. (2006). The role of technology readiness in customer perception and adaptation of self-service technologies. International Journal of Service Industry Management, 17(5), 497-517.

Llosa, S., Chandon, J.L., \& Orsingher, C. (1998). An empirical study of SERVQUAL's dimensionality. The Service Industries Journal, 18(2),16-44.

Loiacono, E.T., Watson, R.T., \& Hoodhue, D.L. (2002). WEBQUAL: Measure of website quality. Marketing Educators Conference: Marketing theory and applications, 13, 432-437.

Macintosh, G., \& Lockshin, L. S. (1997). Retail relationships and loyalty: A multi-level perspective. International Journal of Research in Marketing, 14(5), 487-497.

Malhotra, P., \& Singh, B. (2007). Determinants of internet banking adoption by banks in India. Internet Research, 17(3), 323-339.

Meuter, M., Ostrom, A., Roundtree, R., \& Bitner, M., (2000). Self-service technology: Understand customer satisfaction with technology-based service encounters. Journal of Marketing, 64(3), 5064.

Mukherjee, A, \& Nath, P. (2003). A Model of Trust in Online Relationship Banking. International Journal of Bank Management, 21(1), 5-15.

Nguyen, T., Sherif, J., \& Newby, M. (2007). Strategies for successful CRM implementation. Information management and Computer security, 15(2), 76-95.

Nunnally, J.C., \& Bernstein, H. (1994). Psychometric Theory. New York, McGraw-Hill

Oliver, R. L. (1981). A cognitive model of the antecedents and consequences of satisfaction decisions. Journal of Marketing Research, 17, 460-469.

Parasuraman, A., Berry, L. L., \& Zeithaml, V. A. (1985), A conceptual model of service quality and its implications for future research. Journal of Marketing, 49, 41-50. 
Parasuraman, A., Zeithaml, V. A., \& Berry, L. L. (1988). A multiple-item scale for measuring consumer perceptions of service quality. Journal of Retailing, 64, 12-37.

Parasuraman, A., Berry, L.L., \& Zeithaml, V.A. (1991). Refinement and reassessment of the SERVQUAL scale. Journal of Retailing, 67(4), 420-450.

Parasuraman, A., Zeithaml, V., \& Berry, L.L. (1994). Reassessment of expectations as a comparison standard in measuring service quality: implications for future research. Journal of Marketing, 58, 111-124.

Parasuraman, A., Zeithaml, V., \& Malhotra, A. (2005). E-S-QUAL: A multiple-item scale for assessing electronic service quality. Journal of Service Research, 7(3), 213-234.

Patricio, L., Fisk, R. \& Cunha, J. (2003). Improving satisfaction with bank service offerings: measuring the contribution of each delivery channel. Managing Service Quality, 13(6), 471-482.

Peng, L. Y. \& Wang, Q. (2006). Impact of relationship marketing tactics (RMTs) on switchers and stayers in a competitive service industry. Journal of Marketing Management, 22, 25-59.

Radecki, L., Wenninger, J. \& Orlow, D. (1997). Industry structure: Electronic delivery's potential effects on retail banking. Journal of Retail banking Service, 19(4), 57-63.

Ramsay, J. \& Smith, M. (1999). Managing customer channel usage in the Australian banking sector. Managerial Auditing Journal, 14(7), 329-338.

Reinartz, W. J. \& Kumar, V. (2003). The impact of customer relationship characteristics on profitable lifetime duration. Journal of Marketing, 67(1), 77-99.

Ravi, V., Mahil, C., \& Vidya Sagar, N. (2007). Profiling of internet banking users in india using intelligent techniques. Journal of Services Research, 6(2), 61-73.

Rowley, J., \& Dawes, J. (2000). Disloyalty: A closer look at non-loyals. Journal of Consumer Marketing, 17(6), 538-549.

Rust, R.T., \& Zahorik, A.J. (1993). Customer satisfaction, customer retention and market share. Journal of Retailing, 69(2), 193-215.

Ruyter, K., Wetzels, M., \& Kleijnen, M. (2001). Customer adoption of e-service: an experimental study. International Journal of Service Industry Management, 12(2), 184-207.

Santos, F. (2003). E-service quality: A model of virtual service quality dimensions. Managing Service Quality, 13(3), 233-246.

Sheth, N. J., \& Parvatiyar, A. (1995). Relationships marketing in consumer markets: Antecedents and consequences. Journal of Academy of Marketing Science, 23(4), 255-271.

So, S.H. (2007). An Empirical Analysis on the operational Efficiency of CRM call

centers in Korea, Call center Industry Research Center.

Szymanski, D. \& Hise, R. (2000). e-satisfaction: an initial Examination. Journal of Retailing, 76(3), 309-322.

Tax, S. S. \& Brown, S. W. (1998a). Recovering and learning from service failures. Sloan Management Review, 40, 75-88.

Teijlingen, E. R., \& Hundley, V. (2001). The importance of pilot studies. Social research UPDATE,.35, http://sru.soc.surrey.ac.uk/SRU35.html (accessed on 16-12-2009)

Weinstein, A. \& Johnson, W. C. (1999c). Designing and delivering superior customer value: concepts, cases, and applications. Boca Raton: CRC Press LLC. p.119a,119b,117c,119d,124$126 \mathrm{e}, 126 \mathrm{f}, 127 \mathrm{~g}$.

Wolfinbarger, M.F., \& Gilly, M.C. (2002). comQ: Dimensionalizing, Measuring and Predicting Quality of the E-tail experience. Working paper, Marketing Science Institute, Cambridge, M.A., $02-100$

Yang, Z., \& Fang, Z. (2004). Online services quality dimension and their relationships with satisfaction: a content analysis of customer reviews of securities brokerage services. The International Journal of Bank marketing, 15(3), 189-206.

Yoo, B., \& Donthu, N. (2001). Developing a scale to measure perceived quality of an Internet shopping site (SITEQUAL). Quarterly Journal of Electronic Commerce, 2(1), 31-46. 
1258

Zeithaml, B., \& Parasuraman, A. (1996). The Behavioral Consequences of Service Quality. Journal of Marketing, 6(2), 31-46. 